\title{
REVIEW
}

\section{Spatial ecology of jaguars, pumas and ocelots: a review of the state of}

\section{knowledge}

Noa GONZALEZ-BORRAJO* Department of Conservation Biology, Doñana

Biological Station, CSIC, E-41092 Seville, Spain.Email: noagonzalez@ebd.csic.es

José Vicente LÓPEZ-BAO Research Unit of Biodiversity (UO/CSIC/PA), Oviedo

University, Mieres, 33600, Spain, and Grimsö Wildlife Research Station, Swedish

University of Agricultural Sciences, 73091, Riddarhyttan, Sweden.

Email:jv.lopezbao@gmail.com

Francisco PALOMARES Department of Conservation Biology, Doñana Biological Station, CSIC, E-41092 Seville, Spain.Email: ffpaloma@ebd.csic.es

*Correspondence author.

\begin{abstract}
1. Knowledge of the spatial ecology of mammalian carnivores is critical for understanding species' biology and designing effective conservation and management interventions. We reviewed the available information about the spatial ecology of jaguars Panthera onca, pumas Puma concolor and ocelots Leopardus pardalis, and examined how sex and extrinsic variables affect their spatial behaviour.
\end{abstract}


2. Sixty-one articles addressing home range, home range overlap, daily net displacement (straight-line distance between two locations on consecutive days), and/or distance of dispersal of the three species were included. Meta-analysis, ANOVA, ANCOVA and beta regression tests were run to analyse differences among species and sexes and to elucidate the influence of other variables, such as latitude and ecoregion, on spatial behaviour.

3. Pumas had on average larger home ranges (mean \pm standard error: $281.87 \pm 35.76$ $\left.\mathrm{km}^{2}\right)$ than jaguars $\left(128.61 \pm 49.5 \mathrm{~km}^{2}\right)$ and ocelots $\left(12.46 \pm 3.39 \mathrm{~km}^{2}\right)$. Intersexual range overlap was higher than intrasexual range overlap in jaguars and pumas. Sex affected the home range size of all three species, but only influenced daily net displacement in ocelots. Ecoregion affected the home range size of all three species but did not significantly affect either the daily net displacement or the dispersal distance of pumas. Latitude affected the home range size of jaguars and pumas. It did not affect daily net displacement or dispersal distance in jaguars and pumas, but did affect daily net displacement in ocelots.

4. Although there was a lack of studies in most countries for the three species, information was particularly lacking in the Neotropics for jaguars and pumas and in North America for ocelots. Researchers usually presented low sample sizes, and used different methods to examine the ecological issues considered here. Homogenization of methods is needed to clarify the ecology of these species and to allow a better understanding of the threats to their populations.

Running head: Spatial behaviour of large American felids 
Key words: American felids, dispersal distance, distance travelled, home range size, home range overlap.

Submitted: 3 September 2015

Returned for revision: 2 November 2015

Revision accepted: 22 July 2016

Editors: $\mathrm{KH}$ and DR

\section{INTRODUCTION}

The spatial ecology of species, including carnivorous mammals, is the result of particular tactics chosen by individuals to maximize fitness in response to intrinsic and extrinsic factors (Erlinge \& Sandell 1986). The study of spatial ecology is needed to inform the design of management and conservation interventions, particularly for those species that are scarce and lead secretive lives. For example, non-invasive survey tools can be used to make robust estimates of population size, composition and dynamics, and to evaluate the effectiveness of conservation interventions (Quigley \& Crawshaw 1992, Noss et al. 1996, Carroll et al. 2001, Balme et al. 2009, Grémillet \& Boulinier 2009, López-Bao et al. 2010). Studies of spatial ecology are critical for understanding the natural history, population dynamics, and intraspecific interactions of species.

Solitary carnivore species are characterised by the rarity of direct contact between adults of the same sex (Kleiman \& Eisenberg 1973, Ferreras et al. 1997, López-Bao et al. 2014). Encounters usually only take place during the mating season (Gittleman 1989, Caro 1994, López-Bao et al. 2008). Felids, with the exception of lions Panthera leo 
(Schenkel 1966, Schaller 1972), cheetahs Acinonyx jubatus (Eaton 1970), and domestic cats Felis catus (Corbett 1979), are considered to be solitary carnivores. Comprehensive studies of the spatial ecology of solitary carnivores are rare (Jackson \& Ahlborn 1988, Grassman Jr et al. 2005). For Neotropical felids, they are particularly lacking and fragmented (Cavalcanti \& Gese 2009), and very low sample sizes are the norm (e.g. Schaller \& Crawshaw 1980, Konecny 1989).

For mammals in general and carnivores in particular, home range size and daily movements have been related to body weight or size, and larger ranges and movements occur in heavier species and individuals (Harestad \& Bunnell 1979, Lindstedt et al. 1986). In addition, sex is an important intrinsic factor affecting the spatial ecology of solitary carnivores; while the spatial distribution of females is mainly modulated by the availability of trophic resources, male distribution is also determined by female distribution. Thus, males usually hold larger home ranges (and thus exhibit longer daily movements) than females (Sandell 1989). Females usually hold exclusive territories (Bailey 1974, López-Bao et al. 2014), whereas males are territorial year-round and generally include one or more female home ranges within their territories (Hahn 2001). Nevertheless, non-territorial behaviour has been reported for some species outside the mating period (Seidensticker et al. 1973, Logan et al. 1986, Sandell 1989, Sunquist \& Sunquist 2002). For example, when timing and spacing of available food varies, less territorial behaviour is expected, and individuals show overlapping ranges (Sandell 1989). Although both sexes of solitary carnivores may disperse, dispersal is more common in males than in females, and males usually move greater distances (Smith et al. 1987, Maehr et al. 1991, Laing \& Lindzey 1993, Ferreras et al. 2004). Besides sex, other factors such as prey density (Schaller 1972, Ward \& Krebs 1985, Elbroch \& Wittmer 2012), habitat productivity (Harestad \& Bunnell 1979, Gomper \& Gittleman 
1991), and population density (Seidensticker 1976, Nagy \& Haroldson 1990, Elbroch \& Wittmer 2012) have been reported as factors affecting the spatial ecology of solitary carnivores.

Despite the existence of some studies on the spatial ecology of jaguars Panthera onca, pumas Puma concolor, and ocelots Leopardus pardalis, there is a lack of consistent information about their spatial behaviour. The information available about these felids is not conclusive due to the different techniques used (such as telemetry or cameratrapping) or the different methods employed to estimate home ranges (such as kernel or minimum convex polygon $[\mathrm{MCP}]$ methods). In addition, some areas have not been studied at all. A review of all available information about these cryptic species is needed to draw practical conclusions about their spatial behaviour and to identify gaps in the available knowledge. More complete information is necessary to develop suitable and consistent conservation plans.

Through a comprehensive literature review, we aim to summarize what we know about the spatial ecology of the largest Neotropical felids: jaguars, pumas, and ocelots. We focus our attention on studying home range size, home range overlap, daily movements, and dispersal behaviour. Jaguars are the heaviest of the three species (48 - $100 \mathrm{~kg}$; Scognamillo et al. 2003, De Azevedo 2006), followed by pumas (25 - $89 \mathrm{~kg}$; Scognamillo et al. 2003) and ocelots (7 - $13 \mathrm{~kg}$; Tewes 1986, Crawshaw 1995). In this review, we examine the following hypotheses: 1) jaguars, because they are typically heavier than the other species, have the largest home ranges, the longest daily movements and the furthest dispersal distances of the three species; ocelots present the lowest values and pumas intermediate values. 2) Males have larger home range sizes, longer daily net displacement, and disperse more frequently and longer distances than 
females in all three species. 3) Both males and females of the three species present territorial behaviour. Males contain one or more female territories within their territories, whereas females only include part of a male territory within their range (so that they have a polygamous mating system). Consequently, intersexual range overlap is higher than intrasexual range overlap.

\section{METHODS}

\section{Literature review}

A comprehensive and systematic literature review on the spatial ecology of jaguars, pumas and ocelots was carried out using scientific databases such as ISI Web of Science, PubMed and Google Scholar, compiling studies that spanned the period 19802013. The literature search was carried out using a number of filters based on a set of keywords in English and in Spanish (common and scientific names of jaguar, puma and ocelot, home range, territory, spatial organization, dispersal distance, and daily movement). Information was taken from $\mathrm{PhD}$ and Masters theses, scientific papers, and other types of research projects (see Appendixes S1 - S4). We only considered papers in which radio-tracking or telemetry were used as techniques of study, and excluded studies in which separate information for males and females was not provided.

\section{Data collection}

From each study we extracted mean values, sample sizes and standard deviations for each sex and species for the spatial variables we were interested in: home range size, daily net displacement (as the straight-line distance between two locations on 
consecutive days), and distance travelled during dispersal movements (measured as the straight line from the natal centre to the centre of the newly established home range). To test for territorial behaviour and analyse the home range overlap of the species, we used the studies that provided information about the percentage of home range overlap between and within sexes. For all the parameters, we used annual data when they were available. When data were provided for several years, we calculated the average of those years. In cases where the data were separated by season, we calculated the mean annual data. If no information about the season was available we considered the data to be annual.

For each study, we extracted complementary information: 1) the geographical coordinates of the study area (when latitude and longitude coordinates were not provided, we obtained them by estimating the centroid of the study area); 2) the ecoregion (following the terrestrial classification made by Olson et al. 2001; Fig. 1); 4) the mean weight of each sex and population (when this was not provided, we assigned weight values from other studies of similar latitude and ecoregion; to minimize the potential noise introduced by this assumption, we sorted body weight into $15 \mathrm{~kg}$ bins); 4) method of home range estimation (MCP or kernel density estimation). Studies in which $95 \%$ and $100 \%$ of locations were used to estimate MCP were pooled as "MCP home range estimating method". Similarly, studies in which 85,90 and $95 \%$ probability contour of location distributions were used for kernel density estimation were pooled as "kernel home range estimating method". We did not expect the simultaneous use of studies with different home range estimating methods to introduce a significant bias (e.g., Nilsen et al. 2008 did not find significant differences between the two methods when analysing comparative studies with large variations in home range sizes). As care must be taken when using the MCP method for intraspecific comparisons, we tested 
whether the type of home range estimating method introduces bias by analysing the differences in the home range sizes calculated by the two estimators via ANOVA and ANCOVA tests.

\section{Data analysis}

Due to the variability of the existing data, different analyses were run with the information available. ANOVA and ANCOVA tests, meta-analyses and beta regression tests were used according to the type of variables and the information available (Table 1). Meta-analysis takes into account the quality of the studies, but we could only analyse the influence of sex on the spatial variables. ANOVA and ANCOVA tests are less specific, since they treat all data equally. However, we could analyse the influence of sex, ecoregion and latitude on the different spatial variables with these tests, and required fewer data to do these analyses. Finally, beta regression tests were used when the data were given in proportions.

Firstly, an ANOVA was run to test differences in the mean home range sizes between populations (both sexes pooled; mean home range size used as a dependent variable), with species, mean body weight per population and method of home range estimation used as predictors (explanatory variables). As the three species showed different mean weights, we included the interaction term between species and weight in the model.

We assessed gender differences in home range size and dispersal distance using the meta-analysis packages "metaphor" and "MAd" (Del Re \& Hoyt 2010, Viechtbauer \& Viechtbauer 2015). Both packages include a collection of functions for conducting meta-analysis in $\mathrm{R}$, including functions to calculate the effect size or to fit fixed, random and mixed effects models, among others. In our analysis, random effects models 
(Hedges \& Vevea 1998) were used to account for the variability between effect sizes, which was due not only to sampling error but also to the variability in the population effects. The meta-analysis approach was only applied when information on the number of individuals, as well as the means and standard deviations for our parameters, were available for each sex and study. With these data we calculated the effect size, a standardized index of each study used to compare the quality of the studies. Specifically, we used the standardized mean difference Hedges' g (Hedges 1981) and its associated variance as effect size. The influence of sex was tested, along with the potential influence of latitude and ecoregion, on the different spatial variables. We tested this potential influence when the meta-analysis confirmed significant effects of sex (Viechtbauer 2010). We added these two moderators because variation in the different aspects of the spatial ecology of solitary carnivores is related to ecoregion and latitude (Gompper \& Gittleman 1991, Herfindal et al. 2005). In fact, Gompper and Gittleman (1991) found a significant positive correlation between latitude and home range size, and Herfindal et al. (2005) documented a clear relationship between home range size and study area productivity. Consequently, as latitude can be used as a measure of environmental productivity (Buskirk \& McDonald 1989, Gompper \& Gittleman 1991), we also studied the influence of latitude on the home range size (Harestad \& Bunnell, 1979).

We did not find sufficient data to run a meta-analysis for the daily net displacement or for the home range overlap (studies lacked the standard deviation and/or number of individuals surveyed). For the spatial parameters with insufficient data, we used ANCOVAs with a type III sum of squares. Mean values for home range size, daily net displacement, and dispersal distance were the dependent variables; sex, latitude, ecoregion and home range estimating method were the explanatory variables. A 
different model was run for every dependent variable and for each species. For jaguars and pumas, the home range was calculated both with the kernel and the MCP method. All the home ranges in ocelots were calculated with the MCP method.

To analyse the home range overlap of each species, we assessed the existence of differences in the proportion of home ranges shared by individuals of the same or different sex with beta regression tests (Ferrari \& Cribari-Neto 2004) using the "betareg" package (Zeileis et al. 2012). We used the proportion of home range shared in each sex category for each population as a dependent variable, and gender, sex-specific mean home range sizes and ecoregion as predictors. We included the sex-specific mean home range sizes in each population to control for the potential effect that home range size can have on the percentage of home range overlap (Sandell 1989, Sunquist \& Sunquist 2002).

Prior to conducting the analyses, we tested whether our data met the assumptions of normality and homoscedasticity by running Shapiro and Breusch-Pagan tests, respectively (Shapiro \& Wilk 1965, Breusch \& Pagan 1979). If needed, variables were $\log$ transformed to approach a normal distribution. Statistical analyses were carried out using R Software v.3.0.2 (Anonymous 2007).

\section{RESULTS}

\section{Data set}

The literature search yielded 61 studies providing information on one or more aspects of the spatial ecology of jaguars, pumas and/or ocelots (Table 2). Overall, home range size, 
daily net displacement and dispersal distance were studied mainly in pumas (62 cases) and less in the other two species (20 and 17 cases in jaguars and ocelots, respectively). Home range size was the most-studied subject in large Neotropical felids, and dispersal distances was the least studied (Table 2). Information about dispersal distances was provided in only 11 studies, all of them on pumas. We did not find any studies reporting information on daily net displacement for jaguars (Table 2). Data about home range overlap of territories was only found for jaguars and pumas, and was not found for ocelots.

Information on the spatial ecology of the three species is lacking in most countries in which they are present. Studies on jaguar were mainly carried out in the tropical and subtropical ecoregions (moist and dry broadleaf forests and flooded grasslands and savannas). Studies on ocelots, and especially pumas, were distributed in a wide range of ecoregions from tropical and subtropical ecoregions to temperate and Mediterranean forests, including desert and xeric shrublands (Fig. 1). Most (80\%) of the studies on jaguar were conducted in Brazil or at the border between Brazil and Argentina; the rest (20\%) were carried out in Belize, Bolivia, Mexico and Paraguay. Most (90\%) of the studies on pumas were carried out in the USA and Canada, and only $10 \%$ were conducted in South America (Chile, Paraguay and Brazil; Fig. 1). All the studies on ocelots were conducted in Central and South America, except for three studies carried out in Texas, USA (Fig. 1).

\section{Interspecific differences}

HOME RANGE 
Jaguar and puma home range sizes varied from 22 to $690 \mathrm{~km}^{2}$ and from 37 to $755 \mathrm{~km}^{2}$, respectively; in ocelots they ranged from 2 to $39 \mathrm{~km}^{2}$ (Table 3). On average, pumas had the largest home ranges of the three species, twice the mean home range size of jaguars (Table 3). Ocelots had the smallest home range sizes (Table 3). Body weight had a slight positive influence on the home range size of jaguars and ocelots, but negatively influenced puma home range size (Fig. 2). Nevertheless, the interaction between species and body weight was significant $(\mathrm{F}=10.75 ; \mathrm{P}=0.002$, $\mathrm{df}=1)$, indicating that both species and body weight influence the size of the home range, but that the effect of body weight depends on the species. The $\mathrm{R}^{2}$ values for jaguars and pumas were relatively small, indicating that the influence of body weight on the home range size is small. In addition, the lack of a wide range of data and the strong influence of a single point in pumas and ocelots makes it difficult to identify a clear relationship between the two variables.

\section{DAILY NET DISPLACEMENT AND DISPERSAL DISTANCE}

Daily net displacement was significantly larger in pumas than in ocelots $(\mathrm{F}=10.04, \mathrm{P}=$ 0.013 , df $=1$; Table 4). Information about dispersal behaviour was only available for pumas (Table 2); they travelled a mean distance of $70.48 \mathrm{~km} \pm 16.31(\mathrm{n}=12)$ from the maternal home range to the settlement area.

\section{Intraspecific differences}

\section{HOME RANGE}

Four studies on jaguars, 11 on pumas and five on ocelots provided sufficient information to run a meta-analysis (as described above). Mean home ranges of males 
were always larger than those of females for the three species (Table 3), although the meta-analysis only detected significant differences for pumas $(Z=4.06, P<0.001)$ and ocelots $(\mathrm{Z}=2.46, \mathrm{P}=0.014$; Fig. 3). Neither ecoregion nor latitude showed a significant influence on the observed differences in the size of the home range between sexes $(\mathrm{P}>$ 0.110 for all species). The method of home range estimation did not have a significant effect on the differences between sexes in pumas $(Z=-0.37, P=0.713)$.

ANCOVAs including data from all the studies available confirmed the sex-specific results from the meta-analysis. Males had larger home ranges than females in the three species (Table 3$)$ and we detected significant effects of sex in pumas and ocelots $(\mathrm{F}=$ 42.01, $\mathrm{P}<0.001$, df $=1 ; \mathrm{F}=7.13, \mathrm{P}=0.020, \mathrm{df}=1$; for pumas and ocelots, respectively). Only a marginally significant effect was found in jaguars $(\mathrm{F}=3.92, \mathrm{P}=$ $0.060, \mathrm{df}=1)$.

ANCOVAs showed that significant differences in the size of the home range according to the ecoregion existed for all three species: jaguars $(F=4.48, P=0.010$, $\mathrm{df}=4)$, pumas $(\mathrm{F}=7.72, \mathrm{P}<0.001, \mathrm{df}=6)$ and ocelots $(\mathrm{F}=10.64, \mathrm{P}=0.001, \mathrm{df}=2)$. Jaguars and pumas had the largest home ranges in the tropical and subtropical grasslands, savannas and shrubland ecoregions. However, jaguars had the smallest home ranges in regions predominated by moist broadleaf forest. Pumas had their smallest home ranges in areas predominated by dry broadleaf forest (Table 5). Conversely, ocelots had the largest home ranges in ecoregions where jaguars had their smallest home ranges (the tropical and subtropical moist broadleaf forest). The smallest home ranges of ocelots were in desert and xeric shrublands (Table 5).

ANCOVAs showed that a significant effect of latitude on the home range sizes of jaguars existed $(\mathrm{F}=4.44, \mathrm{P}=0.050, \mathrm{df}=1)$; jaguars had larger home ranges at 
intermediate latitudes. The jaguar population with the largest home range was located in Brazil $\left(690.21 \mathrm{~km}^{2}\right)$, while the population with the smallest home range was in Belize $\left(21.95 \mathrm{~km}^{2}\right)$. ANCOVAs also showed that latitude had a significant effect on the home range sizes of pumas $(\mathrm{F}=12.86, \mathrm{P}=0.001, \mathrm{df}=1)$; pumas had the smallest home ranges in Paraguay and Venezuela (36.81 and $62.75 \mathrm{~km}^{2}$, respectively) and the largest home ranges in Utah and California, USA (755.5 and $492.5 \mathrm{~km}^{2}$ ). In latitudes between 30 and 50 degrees, puma home ranges ranged between 100 and $400 \mathrm{~km}^{2}$. For ocelots, ANCOVAs did not show a significant effect of latitude on home range sizes $(\mathrm{F}=0.16$; $\mathrm{P}=0.695 \mathrm{df}=1)$

The method of home range estimation did not have a significant effect on home range sizes of jaguars and pumas $(\mathrm{F}=0.23, \mathrm{P}=0.630, \mathrm{df}=1 ; \mathrm{F}=0.53, \mathrm{P}=0.590, \mathrm{df}=1$; jaguars and pumas, respectively). However, the largest values of home range size were estimated using the MCP method (Fig. 4).

\section{HOME RANGE OVERLAP}

For jaguars and pumas, intersexual range overlap was larger than intrasexual range overlap (Table 6). In fact, beta regression tests showed significant differences in the percentage of overlap between sexes (jaguar: $\mathrm{Z}=2.63, \mathrm{P}=0.008$; puma: $\mathrm{Z}=3.42, \mathrm{P}=$ 0.001). In jaguars, intrasexual overlap did not differ in either sex (within males: $Z=-$ $1.51, P=0.131$; within females: $\mathrm{Z}=-0.024, \mathrm{P}=0.981$ ), while significant differences in both sexes were found in pumas (in males $\mathrm{Z}=-3.19, \mathrm{P}=0.001 ; \mathrm{Z}=2.37, \mathrm{P}=0.018$ ). The interaction between home range size and sex was not significant in jaguars (intersexual interaction, $\mathrm{Z}=-1.72, \mathrm{P}=0.084$; intrasexual interaction, $\mathrm{Z}=1.14, \mathrm{P}=$ 
0.254). In pumas, the intrasexual interaction did show a significant effect $(Z=3.11, P=$ $0.002)$.

\section{DAILY NET DISPLACEMENT AND DISPERSAL DISTANCE.}

We only found daily net displacement data for pumas and ocelots (Table 2), and these data were insufficient for meta-analyses (Table 4).

The results of the ANCOVA showed that, for pumas, sex $(\mathrm{F}=0.02, \mathrm{P}=0.888, \mathrm{df}=1$; Table 4) ecoregion $(\mathrm{F}=1.21, \mathrm{P}=0.398, \mathrm{df}=4)$, and latitude $(\mathrm{F}=1.18, \mathrm{P}=0.320, \mathrm{df}=$ 1) did not significantly affect the daily net displacement of pumas. In ocelots, both sex $(\mathrm{F}=12.40, \mathrm{P}=0.039 ;$ Table 4$)$ and latitude $(\mathrm{F}=10.18, \mathrm{P}=0.049, \mathrm{df}=1)$ showed a significant effect on the mean daily net displacement. All the studies on ocelots were carried out in the tropical and subtropical moist broadleaf forest ecoregions.

Dispersal distances in pumas were greater in males $(97.94 \pm 18.39 \mathrm{~km}, \mathrm{n}=12)$ than in females $(37.54 \pm 5.26 \mathrm{~km}, \mathrm{n}=10)$. Both the meta-analysis $(\mathrm{Z}=2.21, \mathrm{P}=0.026)$ and the ANCOVA $(\mathrm{F}=14.41, \mathrm{P}=0.001, \mathrm{df}=1)$ showed that significant differences existed between sexes. No significant effect of ecoregion $(F=0.65, \mathrm{P}=0.593$, $\mathrm{df}=3)$ or latitude $(\mathrm{F}=0.74, \mathrm{P}=0.403, \mathrm{df}=1)$ was found.

\section{DISCUSSION}

This review contributes to our understanding of the natural history of the largest Neotropical American felids: jaguars, pumas and ocelots. Although our data indicate 
that spatial information for these species is still scarce and fragmented, we were able to draw some conclusions unifying the information available and, in some cases, confirm findings of previous studies on these solitary carnivores.

The studies on jaguars were mainly conducted in Brazil, Paraguay, Bolivia and Belize (data available in Appendices S1 and S2). Jaguars were relatively unstudied in the northern and central part of their range, though a few studies took place in Mexico and northern South America. Puma spatial ecology has been well studied in temperate and subtropical areas of North America (e.g., Anderson 1983, Currier 1983, Hansen 1992), but is relatively unstudied in the Neotropical region: we found just four studies from South America (Brazil, Paraguay and Chile; data available in Appendices S1-S4). Fragmentation of information also exists for ocelots; most of the studies were conducted in Belize, Argentina, Peru, Bolivia and Brazil (only one study was carried out in North America; data available in Appendices S1 and S3). Information about the spatial ecology of pumas is the most complete; information about home range sizes, daily movements, dispersal and territoriality is relatively abundant. Conversely, for jaguars, information about daily movements and dispersal is non-existent, and for ocelots, only information about home range and daily movement is available. Our analyses revealed a significant amount of variation between studies. More information drawn from a greater sample size and in different contexts is needed to clarify the spatial ecology of these species. Moreover, homogenization of the methods used for data collection and to study the spatial ecology of these species is needed. We recommend following a unified methodology for estimating animal home ranges (Laver \& Kelly 2008).

The spatial behaviour of mammalian carnivores has often been related to body weight or size, and larger home ranges and daily movements are usually detected in bigger, heavier animals (McNab 1963, Harestad \& Bunnell 1979, Lindstedt et al. 1986). 
However, we found that pumas, rather than jaguars (the heaviest species), showed the largest home ranges of the Neotropical felids. With the exception of Silveira (2004), who found that the home range sizes of jaguars were as large as those of pumas, all the largest home ranges were observed in pumas in the USA. These home ranges were even larger than those of jaguars from the Pantanal region of Brazil, where the jaguars are among the heaviest of the American felids (> $90 \mathrm{~kg}$; e.g. De Azevedo 2006). It is known that other factors besides body weight, such as latitude, habitat productivity, type of prey and ecoregion, affect the size of the home range (Lindstedt et al. 1986, Sandell 1989). The effects of these other variables may explain why jaguars did not have the largest home ranges, and why, in some locations, the lighter pumas showed larger home ranges. Most of the puma studies were conducted in North America, whereas all the jaguar studies were conducted in Central and South America, zones with different ecoregions.

Within species, we observed a relationship between body weight and home range size in jaguars and ocelots: the lightest jaguars were in Mexico and Belize $(<50 \mathrm{~kg}$; Rabinowitz \& Nottingham 1986, Ceballos et al. 2005), as were the smallest home range sizes (46 and $10.5 \mathrm{~km}^{2}$, respectively). The heaviest jaguars were from the Pantanal region (> $90 \mathrm{~kg}$; De Azevedo 2006), where the largest home range sizes were observed (> $900 \mathrm{~km}^{2}$; Silveira 2004). As we expected, the lightest species, the ocelot, had the smallest home ranges, and the heaviest ocelots (13 kg, Crawshaw 1995) had the largest home ranges (Brazil - Argentina and Belize; $39 \mathrm{~km}^{2}$ ). In pumas, however, we did not observe as clear a pattern. We observed contrasting patterns in North America and South-Central America: pumas in South-Central America showed similar spatial behaviours, while in North America, pumas (even from the same state) showed contrasting patterns in home range sizes. This different spatial behaviour between 
different populations may be caused by factors affecting the density and population dynamics, such as prey density, context-specific vegetative-topographic factors, management, or habitat fragmentation due to human development (Hemker et al. 1984, Stoner et al. 2006, Maletzke et al. 2014).

Body weight seems to influence the felids' daily net displacement: greater distances are travelled by heavier species. We observed a positive relationship between body weight of the species and daily net displacement: pumas travelled a greater daily mean distance than ocelots. Nevertheless, and because for jaguars there was no information about daily net displacement, we cannot draw a reliable conclusion regarding the relationship between body weight and daily net displacement. More studies about the daily movement of jaguars are needed to draw conclusions about the relationship between body weight and daily net displacement between these three species.

Males of the three species had larger home ranges and travelled greater distances than females, in agreement with previous studies suggesting sexual differences in the spatial behaviour of carnivores (Smith et al. 1987, Sandell 1989, Maehr et al. 1991, Laing \& Lindzey 1993). As an exception to this, and in contrast to most of the studies about the spatial ecology of these felids (Appendix S1), studies on jaguars in Mexico (3 males and 3 females; Ceballos et al. 2005), pumas in Chile (4 males and 2 females; Franklin et al. 1999), and pumas in Vancouver, Canada (2 males and 11 females; Shackleton 2000) showed that adult females had larger home ranges than adult males. None of these authors attached any special significance to their results; they used telemetry and the MCP method. Sexual differences in home range size were more pronounced in pumas than in jaguars and ocelots. In most studies on pumas, the home range size of males was twice that of females (Table 2). 
Our results also showed sexual differences in movement patterns. As observed in other cats (e.g. in the Eurasian lynx Lynx lynx, Jedrzejewski et al. 2002), male ocelots travelled greater daily net distances than females. Nevertheless, as Dickson et al. (2005) and Elbroch and Wittmer (2012) found, we did not observe differences in the daily net distance travelled by male and female pumas. Sex did affect the distance travelled by pumas during the dispersal period, when male pumas travel greater distances than females (Trewhella et al. 1988) as a consequence of female philopatry (Ross \& Jalkotzy 1992, Lindzey et al. 1994; Sweanor et al. 2000): females tend to settle closer to the territory where they were born than males.

We found latitudinal patterns in the spatial ecology of the felids, and such effects were stronger in pumas than in jaguars. Pumas had smaller home ranges near Ecuador (Paraguay and Venezuela) and larger home ranges in the USA. In addition, a relationship between ecoregion and home range size in both species was detected: jaguars and pumas had larger home ranges in tropical and subtropical grasslands, savannas and shrubland ecoregions. Ocelots had larger home ranges in the tropical and subtropical moist broadleaf forest ecoregions, where jaguars exhibited smaller home ranges.

Contrary to our hypothesis, daily net displacement and dispersal distances were not influenced by latitude or ecoregion. Other factors may have masked these effects, such as topography (Dickson et al. 2005), behaviour of the animals on sampling days (e.g., animals were hunting, eating from a carcass, mating, or females had litters; Beier \& Barret 1993, Beier et al. 1995). Dispersal distance could also have been affected by the territory in which the animal was travelling, by the presence of human settlements and roads that can act as barriers, or by other extrinsic variables (Beier \& Barret 1993). 
We did not find sufficient data for jaguars on home range overlap and relationships between neighbours to assess their mating system. However, two studies from Brazil provided specific information about the spatial organization of the neighbouring individuals. Cavalcanti and Gese (2009), using the MCP method, found a spatial structure where more than one male overlapped with one or more females. De Azevedo (2006), on the other hand, using the kernel method, found that both males and females showed a high degree of overlap: one individual of each sex overlapped its home range with that of more than two individuals of the same sex and more than three individuals of the other sex.

For pumas, ten studies provided information about the home range overlap between neighbours. In these studies, three different spatial organization structures were detected. In the first structure, males with no overlap between them encompassed overlapping female home ranges (Logan et al. 1986, Shackleton 2000, Hahn 2001). In all of these studies, the MCP method was used and they were carried out in the temperate conifer forest ecoregion. In the second structure, males and females did not show intra-sex overlap. In the one study showing this structure, the MCP method was used in the temperate conifer forest ecoregion (Spreadbury et al. 1996). In the third structure, in three studies overlap was found between both males and females; male home ranges encompassed the home ranges of other males and of several females. In two of these studies, the MCP method was used and they were carried out in North America, one in a temperate conifer forest (Neal et al. 1987), and the other in desert and xeric shrublands (Anderson et al. 1992). The third study was conducted in Chile in temperate broadleaf and mixed forest, using the kernel method (Elbroch \& Wittmer 2012). 
These contrasting results may be due to the methods used to estimate home ranges, or to influences of the ecoregion. Thus, our review indicates that our knowledge on the social system of jaguars, pumas and ocelots and the interactions between and within sexes is still limited. Available information shows that home ranges of different sexes in both jaguars and pumas overlapped by more than 50\%. However, intrasexual behaviour differed between pumas and jaguars. Female jaguars seemed to be more territorial than males (Palomares et al. 2012), although both sexes showed some degree of intrasexual overlap. Contrary to this, male pumas were more territorial than females; females showed twice the percentage of home range overlap of males. A polygynous mating system was more often observed in pumas, where one male has an exclusive relationship with two or more females. In jaguars, just two studies provided information about the mating system, and neither of these showed a polygynous mating system in which two or more males shared the same females (Palomares et al. 2012).

Jaguars, pumas and ocelots are threatened by habitat loss, poaching and conflicts with humans (e.g. livestock predation, Patterson et al. 2004, Michalski et al. 2006). With this review we contribute to our understanding of the spatial ecology of the largest American felids, and demonstrate that spatial information for these species remains scarce and fragmented. This has substantial implications for conservation and management at the landscape scale. In general, more studies about the spatial ecology of these three species are needed so that reliable conclusions and area-specific conservation plans can be made. Specifically, studies about movement ecology in jaguars and ocelots are needed, both for daily net distance and dispersal information; studies on the whole distribution of both species are also needed. Although for pumas there is information on the different aspects of their spatial ecology, the studies were mainly conducted in the northern part of their geographical range, and there is just some 
information on the central and southern parts. Homogenisation of the methods used, both for the fieldwork and for analysis, is needed, to allow comparison of all the information derived from the different studies.

\section{ACKNOWLEDGEMENTS}

This study was carried out with the support of project CGL2010-16902 from the Spanish Ministry of Research and Innovation, project CGL2013-46026-P from the Spanish Ministry of Economy and Competitiveness, the excellence project RNM 2300 from Junta de Andalucía, an F.P.U fellowship from the Spanish Ministry of Education (AP2010-5373), and a 'Juan de la Cierva' research contract (JCI-2012-13066) from the Spanish Ministry of Economy and Competitiveness. We are grateful to Bart Harmsen, Néstor Fernández, Pablo Burraco and Christoph Liedtke for their interest and for their help with the analysis and correction of the manuscript.

\section{REFERENCES}

Anderson AE (1983) A Critical Review of Literature on Puma (Felis concolor)(No. 54). Colorado Division of Wildlife, Colorado, USA.

Anderson MG, Rhymer JM, Rohwer FC (1992) Philopatry, dispersal, and the genetic structure of waterfowl populations. In: Batt BD, Afton AD, Anderson MG, Ankney CD, Johnson DH, Kadlec JA, and Krapu GL (eds) Ecology and Management of Breeding Waterfowl, 365-395. University of Minnesota Press, Minneapolis USA.

Anonymous (2007) R Development Core Team. https://www.r-project.org/ 
Bailey TN (1974) Social organization in a bobcat population. The Journal of Wildlife Management 38: 435-446.

Balme GA, Slotow R, Hunter LT (2009) Impact of conservation interventions on the dynamics and persistence of a persecuted leopard (Panthera pardus) population. Biological Conservation 142: 2681-2690.

Beier P, Barrett RH (1993) The Cougar in the Santa Ana Mountain Range, California. Final report, Orange County Cooperative Mountain Lion Study, Department of Forestry and Resource Management. University of California, Berkeley, USA.

Beier P, Choate D, Barrett RH (1995) Movement patterns of mountain lions during different behaviours. Journal of Mammalogy 76: 1056-1070.

Breusch TS, Pagan AR (1979) A simple test for heteroscedasticity and random coefficient variation. Econometrica 47: 1287-1294.

Buskirk SW, McDonald LL (1989) Analysis of variability in home-range size of the American marten. The Journal of Wildlife Management 53: 997-1004.

Caro TM (1994) Cheetahs of the Serengeti Plains: Group Living in an Asocial Species. University of Chicago Press, Chicago, USA.

Carroll C, Noss RF, Paquet PC (2001) Carnivores as focal species for conservation planning in the Rocky Mountain region. Ecological Applications 11: 961-980.

Cavalcanti SM, Gese EM (2009) Spatial ecology and social interactions of jaguars (Panthera onca) in the southern Pantanal, Brazil. Journal of Mammalogy 90: 935-945.

Ceballos G, Chávez C, Zarza H, Manterola C (2005) Ecología y conservación del jaguar en la región de Calakmul. Biodiversitas 62: 1-7. 
Corbett LK (1979) Feeding Ecology and Social Organization of wildcats (Felis silvestris) and Domestic Cats (Felis catus) in Scotland. $\mathrm{PhD}$ thesis, University of Aberdeen, Aberdeen, UK.

Crawshaw PG (1995) Comparative Ecology of Ocelot (Felis pardalis) and Jaguar (Panthera onca) in a Protected Subtropical Forest in Brazil and Argentina. $\mathrm{PhD}$ thesis, University of Florida, Florida, USA.

Currier MJP (1983) Felis concolor. Mammalian species 200: 1-7.

De Azevedo FCC (2006) Predation patterns of jaguars (Panthera onca) in a seasonally flooded forest in the southern region of Pantanal, Brazil. PhD thesis, University of Idaho, Idaho, USA.

Del Re AC, Hoyt WT (2010) MAd: Meta-analysis with mean differences. R package versión 0.8, http://CRAN.R-project.org/package=MAd. Madison, Wisconsin, USA

Dickson BG, Jenness JS, Beier P (2005) Influence of vegetation, topography, and roads on cougar movement in southern California. Journal of wildlife Management 69: 264276.

Eaton RL (1970) Hunting behaviour of cheetah. Journal of Wildlife Management 34: $56-67$.

Elbroch LM, Wittmer HU (2012) Puma spatial ecology in open habitats with aggregate prey. Mammalian Biology 77: 377-384.

Erlinge S, Sandell M (1986) Seasonal changes in the social organization of male stoats, Mustela erminea: an effect of shifts between two decisive resources. Oikos 47: 57-62. 
Ferrari S, Cribari-Neto F (2004) Beta regression for modelling rates and proportions. Journal of Applied Statistics 31: 799-815.

Ferreras P, Beltrán JF, Aldama JJ, Delibes M (1997) Spatial organization and land tenure system of the endangered Iberian lynx (Lynx pardinus). Journal of Zoology 243: 163-189.

Ferreras P, Delibes M, Palomares F, Fedriani JM, Calzada J, Revilla E (2004) Proximate and ultimate causes of dispersal in the Iberian lynx $\operatorname{Lynx}$ pardinus. Behavioural Ecology 15: 31-40.

Franklin N, Bastoni S, Siswomartono D, Manansang J, Tilson R (1999) Last of the Indonesian tigers: a cause for optimism. In Seidensticker J, Christie S, Jackson P (eds): Riding the Tiger: Tiger Conservation in Human-dominated Landscapes, 130-147. Cambridge University Press, Cambridge, UK.

Gittleman JL (1989) Carnivore group living: comparative trends. In: Gittleman JL (ed). Carnivore Behaviour, Ecology, and Evolution, 183-207. Cornell University Press, Ithaca, USA.

Gompper ME, Gittleman JL (1991) Home range scaling: intraspecific and comparative trends. Oecologia 87: 343-348.

Grassman Jr LI, Tewes ME, Silvy NJ, Kreetiyutanont K (2005) Ecology of three sympatric felids in a mixed evergreen forest in north-central Thailand. Journal of Mammalogy 86: 29-38.

Grémillet D, Boulinier T (2009) Spatial ecology and conservation of seabirds facing global climate change: a review. Marine Ecology Progress Series 391: 121-137. 
Hahn AM (2001) Social and Spatial Organization of Vancouver Island Cougar. PhD thesis, University of British Columbia, British Columbia, Canada.

Hansen K (1992) Cougar, the American lion. Northland Publishing, Flagstaff, Arizona, USA.

Harestad AS, Bunnel FL (1979) Home range and body weight--a reevaluation. Ecology 60: $389-402$.

Hedges LV (1981) Distribution theory for Glass's estimator of effect size and related estimators. Journal of Educational and Behavioural Statistics 6: 107-128.

Hedges LV, Vevea JL (1998) Fixed and random-effects models in meta-analysis. Psychological methods 3: 486.

Hemker TP, Lindzey FG, Ackerman BB (1984) Population characteristics and movement patterns of cougars in southern Utah. The Journal of Wildlife Management 48: $1275-1284$.

Herfindal I, Linnell JD, Odden J, Nilsen EB, Andersen R (2005) Prey density, environmental productivity and home-range size in the Eurasian lynx (Lynx lynx). Journal of Zoology 265: 63-71.

Jackson R, Ahlborn G (1988) Observations on the ecology of snow leopard in west Nepal. In Freeman, H (ed): Proceedings of the 5th International Snow Leopard Symposium , 65-87. International Snow Leopard Trust and Wildlife Institute of India, Seattle, Washington, USA 
Jędrzejewski W, Schmidt K, Okarma H, Kowalczyk R (2002) Movement pattern and home range use by the Eurasian lynx in Białowieża Primeval Forest (Poland). Annales Zoologici Fennici 39: 29-41.

Kleiman DG, Eisenberg JF (1973) Comparisons of canid and felid social systems from an evolutionary perspective. Animal Behaviour 21: 637-659.

Konecny MJ (1989) Movement patterns and food habits of four sympatric carnivore species in Belize, Central America. Advances in Neotropical Mammalogy 1989: 243264.

Laing SP, Lindzey FG (1993) Patterns of replacement of resident cougars in southern Utah. Journal of Mammalogy 74: 1056-1058.

Laver PN, Kelly MJ (2008) A critical review of home range studies. The Journal of Wildlife Management 72: 290-298.

Lindstedt SL, Miller BJ, Buskirk SW (1986) Home range, time, and body size in mammals. Ecology 67: 413-418.

Lindzey FG, Van Sickle WD, Ackerman BB, Barnhurst D, Hemker TP, Laing SP (1994) Cougar population dynamics in southern Utah. The Journal of Wildlife Management 58: 619-624.

Logan KA, Irwin LL, Skinner R (1986) Characteristics of a hunted mountain lion population in Wyoming. The Journal of Wildlife Management 50: 648-654.

López-Bao JV, Rodríguez A, Alés E (2008) Field observation of two males following a female in the Iberian lynx (Lynx pardinus) during the mating season. Mammalian Biology 5: 404-406. 
López-Bao JV, Palomares F, Rodríguez A, Delibes M (2010) Effects of food supplementation on home-range size, reproductive success, productivity and recruitment in a small population of Iberian lynx. Animal Conservation 13: 35-42.

López-Bao JV, Rodríguez A, Delibes M, Fedriani JM, Calzada J, Ferreras P, Palomares F (2014) Revisiting food-based models of territoriality in solitary predators. Journal of Animal Ecology 83: 934-942.

Maehr DS, Land ED, Roelke ME (1991) Mortality patterns of panthers in southwest Florida. Proceedings of the Annual Conference of Southeast Game and Fish and Wildlife Agencies 45: 201-207.

Maletzke BT, Wielgus R, Koehler GM, Swanson M, Cooley H, Alldredge JR (2014) Effects of hunting on cougar spatial organization. Ecology and Evolution 4: 2178-2185. McNab BK. (1963) Bioenergetics and the determination of home range size. American Naturalist 97: 133-140.

Michalski F, Boulhosa RLP, Faria A, Peres CA (2006) Human-wildlife conflicts in a fragmented Amazonian forest landscape: determinants of large felid depredation on livestock. Animal Conservation 9: 179-188.

Nagy JA, Haroldson MA (1990) Comparisons of some home range and population parameters among four grizzly bear populations in Canada. In Darling LM \& Archibald WR (eds): Bears: their Biology and Management, 227-235. Hemlock Printers Ltd for International Association for Bear Research and Management. Vancouver, Canada.

Neal DL, Steger GN, Bertram RC (1987) Mountain Lions: Preliminary Findings on Home-range Use and Density in the Central Sierra Nevada. US Department of 
Agriculture, Forest Service, Pacific Southwest Forest and Range Experiment Station. Berkeley, California, USA.

Nilsen EB, Pedersen S, Linnell JD (2008) Can minimum convex polygon home ranges be used to draw biologically meaningful conclusions? Ecological Research 23: 635639.

Noss RF, Quigley HB, Hornocker MG, Merrill T, Paquet PC (1996) Conservation biology and carnivore conservation in the Rocky Mountains. Conservation Biology 10: 949-963.

Olson DM, Dinerstein E, Wikramanayake ED, Burgess ND, Powell GV, Underwood EC, Kassem KR (2001) Terrestrial ecoregions of the world: a new map of life on Earth. BioScience 51: 933-938.

Palomares F, Roques S, Chavez C, Silveira L, Keller C, Sollmann R et al. (2012) High proportion of male faeces in jaguar populations. PloS one 7: e52923.

Patterson BD, Kasiki SM, Selempo E, Kays RW (2004) Livestock predation by lions (Panthera leo) and other carnivores on ranches neighboring Tsavo National Parks, Kenya. Biological Conservation 119: 507-516.

Quigley HB, Crawshaw PG (1992) A conservation plan for the jaguar (Panthera onca) in the Pantanal region of Brazil. Biological Conservation 61: 149-157.

Rabinowitz AR, Nottingham BG (1986) Ecology and behaviour of the jaguar (Panthera onca) in Belize, Central America. Journal of Zoology 210: 149-159.

Ross PI, Jalkotzy MG (1992) Characteristics of a hunted population of cougars in southwestern Alberta. The Journal of Wildlife Management 56: 417-426. 
Sandell M (1989) The mating tactics and spacing patterns of solitary carnivores. In Gittleman JL, (ed): Carnivore Behaviour, Ecology, and Evolution, 164-182. Springer US.Ithaca, New York, USA.

Schaller GB (1972) The Serengeti Lion. University of Chicago Press, Chicago, USA.

Schaller GB, Crawshaw Jr PG (1980) Movement patterns of jaguar. Biotropica 12: 161168.

Schenkel R (1966). On sociology and behaviour in impala (Aepyceros melampus Lichtenstein). African Journal of Ecology 4: 99-114.

Scognamillo D, Maxit IE, Sunquist M, Polisar J (2003) Coexistence of jaguar (Panthera onca) and puma (Puma concolor) in a mosaic landscape in the Venezuelan llanos. Journal of Zoology 259: 269-279.

Seidensticker JC, Hornocker MG, Wiles WV, Messick JP (1973) Mountain lion social organization in the Idaho Primitive Area. Wildlife Monographs, 35: 1-60.

Seidensticker J (1976) On the ecological separation between tigers and leopards. Biotropica 8: 225-234.

Shackleton D (2000) Forest Renewal BC Research Program. Final Report.In Northwest Bay cougar Project. University of British Columbia, Vancouver, Canada.

Shapiro SS, Wilk MB (1965) An analysis of variance test for normality (complete samples). Biometrika 52: 591-611.

Silveira L (2004) Ecologia comparada e conservação da onça-pintada (Panthera onca) e onça-parda (Puma concolor), no Cerrado e Pantanal. PhD thesis, University de Brasília, Brasília, Brazil. 
Smith JLD, McDougal C, Sunquist ME (1987). Land tenure system in female tigers. In Tilson RL, Seal US (eds.): Tigers of the World: the Biology, Biopolitics, Management and Conservation of an Endangered Species, 97-109. Noyes Publications, Park Ridge, New Jersey, USA.

Spreadbury BR, Musil RK, Musil J, Kaisner C, Kovak J (1996) Cougar population characteristics in southeastern British Columbia. The Journal of Wildlife Management 60: 962-969.

Stoner DC, Wolfe ML, Choate DM (2006) Cougar exploitation levels in Utah: implications for demographic structure, population recovery, and metapopulation dynamics. Journal of Wildlife Management 70: 1588-1600.

Sunquist M, Sunquist F (2002) Wild Cats of the Eorld. University of Chicago Press, Chicago, USA.

Sweanor LL, Logan KA, Hornocker MG (2000) Cougar dispersal patterns, metapopulation dynamics, and conservation. Conservation Biology 14: 798-808.

Tewes ME (1986) Ecological and behavioral correlates of ocelot spatial patterns. $\mathrm{PhD}$ thesis, University of Idaho, Idaho, USA.

Trewhella WJ, Harris S, McAllister FE (1988) Dispersal distance, home-range size and population density in the red fox (Vulpes vulpes): a quantitative analysis. Journal of Applied Ecology 25: 423-434.

Viechtbauer W (2010). Conducting meta-analyses in $\mathrm{R}$ with the metafor package. Journal of Statistical Software 36: 1-48.

Viechtbauer W, Viechtbauer MW (2015) Package 'metafor'. Meta-Analysis Package for $R$, https://cran.r-project.org/web/packages/metafor/metafor.pdf 
Ward RM, Krebs CJ (1985) Behavioural responses of lynx to declining snowshoe hare abundance. Canadian Journal of Zoology 63: 2817-2824.

Zeileis A, Cribari-Neto F, Gruen B, Kosmidis I (2012) Package ' betareg'. https://cran.r-project.org/web/packages/betareg/betareg.pdf.

\section{FIGURE LEGENDS AND TABLES}

Fig 1. Locations (dots) and ecoregions (shaded areas) of the studies on jaguars, pumas and ocelots in America included in this review (after Olson et al., 2001). The distribution of each species is also represented (crosshatching).

Fig 2. Mean home range size and body weight of each population of jaguars, pumas and ocelots. Trend lines show the relationship between body weight and the size of the home range for each species.

Fig 3. Forest plots comparing the mean home range size between males and females of the studies available for the meta-analysis for jaguars (a), pumas (b), and ocelots (c). Information about the authors and year of each study, the mean home range size of males and females of each population (first and second column after the reference) and the mean value of the effect size for every study with $95 \%$ confidence intervals (last column) are shown. 
Fig 4. Mean home range size obtained from the different estimating methods (minimum convex polygon and kernel) in (a) jaguars and (b) pumas. The box plot shows median, 25th and 75th percentiles; whiskers show maximum and minimum values.

Table 1. Statistical approaches used for each spatial variable, and the species for which the approaches were possible given the data available.

\begin{tabular}{|c|c|c|c|c|}
\cline { 2 - 5 } \multicolumn{1}{c|}{} & Home range & Home range overlap & $\begin{array}{c}\text { Daily net } \\
\text { displacement }\end{array}$ & Dispersal \\
\hline $\begin{array}{c}\text { Statistical } \\
\text { approach }\end{array}$ & $\begin{array}{c}\text { ANOVA / Meta- } \\
\text { analysis / ANCOVA }\end{array}$ & Beta regression & ANCOVA & $\begin{array}{c}\text { Meta-analysis / } \\
\text { ANCOVA }\end{array}$ \\
\hline Species & Jaguar/puma/ocelot & jaguar/puma & puma/ocelot & puma \\
\hline
\end{tabular}

Table 2. Number of studies in which information about home range size, home range overlap, daily net displacement and dispersal distances for jaguars, pumas and ocelots was provided. For every species and spatial variable, the number of studies is shown. For home range variables, the number of studies in which the minimum convex polygon and kernel methods were used is indicated in parentheses (MCP/kernel).

\begin{tabular}{|c|c|c|c|c|c|}
\hline Species & Home range size & $\begin{array}{c}\text { Home range } \\
\text { overlap }\end{array}$ & $\begin{array}{c}\text { Daily net } \\
\text { displacement }\end{array}$ & $\begin{array}{c}\text { Dispersal } \\
\text { distances }\end{array}$ & TOTAL \\
\hline Jaguar & $14(12 / 2)$ & $6(4 / 2)$ & 0 & 0 & 20 \\
Puma & $33(18 / 6)$ & $11(8 / 3)$ & 7 & 11 & 62 \\
Ocelot & $11(11 / 0)$ & $0(0 / 0)$ & 3 & 0 & 14 \\
\hline TOTAL & 58 & 17 & 10 & 11 & 96 \\
\hline
\end{tabular}

Table 3. Mean home range sizes for all the studies reviewed and for the studies used in the meta-analysis, for both sexes, and the mean \pm standard error for each species. The 
number of studies is indicated as $\mathrm{n}$. The last rows are the mean values for the home range calculated with the different home range estimating methods.o

\begin{tabular}{|c|c|c|c|c|}
\hline & & & Species & \\
\hline Sex/method & & Jaguar & Puma & Ocelot \\
\hline \multirow{2}{*}{ Males } & $\begin{array}{c}\text { All studies mean }\left(\mathrm{km}^{2}\right) \\
\pm \mathrm{SE} \\
\mathrm{n} \\
\end{array}$ & $\begin{array}{c}187.3 \pm 64.6 \\
14\end{array}$ & $\begin{array}{c}402.1 \pm 36.4 \\
36\end{array}$ & $\begin{array}{c}16.1 \pm 3.6 \\
11 \\
\end{array}$ \\
\hline & $\begin{array}{c}\text { Meta-analysis studies } \\
\text { mean }\left(\mathrm{km}^{2}\right) \pm \mathrm{SE} \\
\mathrm{n}\end{array}$ & $\begin{array}{c}203.3 \pm 132.8 \\
4\end{array}$ & $\begin{array}{c}328.8 \pm 54.9 \\
12\end{array}$ & $\begin{array}{c}20.7 \pm 6.1 \\
5\end{array}$ \\
\hline \multirow[b]{2}{*}{ Females } & $\begin{array}{c}\text { All studies mean }\left(\mathrm{km}^{2}\right) \\
\pm \mathrm{SE} \\
\mathrm{n}\end{array}$ & $\begin{array}{c}88.7 \pm 25.8 \\
14\end{array}$ & $\begin{array}{c}161.5 \pm 20.8 \\
36\end{array}$ & $\begin{array}{c}8.6 \pm 2.4 \\
11\end{array}$ \\
\hline & $\begin{array}{c}\text { Meta-analysis studies } \\
\text { mean }\left(\mathrm{km}^{2}\right) \pm \mathrm{SE} \\
\mathrm{n}\end{array}$ & $\begin{array}{c}149 \pm 97.1 \\
4\end{array}$ & $\begin{array}{c}151.1 \pm 26.4 \\
12\end{array}$ & $\begin{array}{c}14 \pm 4.6 \\
5\end{array}$ \\
\hline \multirow{2}{*}{$\begin{array}{l}\text { Species } \\
\text { average }\end{array}$} & $\begin{array}{c}\text { All studies mean (km2) } \\
\pm \mathrm{SE} \\
\mathrm{n} \\
\end{array}$ & $\begin{array}{c}128.6 \pm 49.5 \\
14\end{array}$ & $\begin{array}{c}281.8 \pm 25.6 \\
36\end{array}$ & $\begin{array}{c}12 \pm 3.1 \\
11 \\
\end{array}$ \\
\hline & $\begin{array}{c}\text { Meta-analysis studies } \\
\text { mean }\left(\mathrm{km}^{2}\right) \pm \mathrm{SE} \\
\mathrm{n}\end{array}$ & $\begin{array}{c}176.2 \pm 76.8 \\
4\end{array}$ & $\begin{array}{c}240 \pm 35.1 \\
12\end{array}$ & $\begin{array}{c}17.4 \pm 3.7 \\
5\end{array}$ \\
\hline \multirow{2}{*}{$\begin{array}{l}\text { Home range } \\
\text { estimation } \\
\text { method }\end{array}$} & $\begin{array}{c}\mathrm{MCP} \\
\mathrm{n}\end{array}$ & $\begin{array}{c}128 \pm 51.9 \\
12\end{array}$ & $\begin{array}{c}264.6 \pm 33 \\
18\end{array}$ & $\begin{array}{c}11.9 \pm 3.1 \\
10\end{array}$ \\
\hline & $\begin{array}{c}\text { Kernel } \\
\mathrm{n}\end{array}$ & $\begin{array}{c}131.9 \pm 79.1 \\
2\end{array}$ & $\begin{array}{c}264.9 \pm 31.7 \\
6\end{array}$ & $\begin{array}{l}- \\
0\end{array}$ \\
\hline
\end{tabular}

Table 4. Daily net displacement for each sex and their pooled averages for pumas and ocelots.

\begin{tabular}{|c|c|c|}
\hline \multicolumn{3}{|c|}{ Distance between daily locations } \\
\hline Males & Females & Average \\
\hline
\end{tabular}




\begin{tabular}{|l|cc|cc|cc|}
\cline { 2 - 7 } \multicolumn{1}{c|}{} & $\begin{array}{c}\text { All studies mean } \\
(\mathrm{km}) \pm \mathrm{SE}\end{array}$ & $\mathrm{n}$ & $\begin{array}{c}\text { All studies mean } \\
(\mathrm{km}) \pm \mathrm{SE}\end{array}$ & $\mathrm{n}$ & $\begin{array}{c}\text { All studies mean } \\
(\mathrm{km}) \pm \mathrm{SE}\end{array}$ & $\mathrm{n}$ \\
\hline Puma & $5.46 \pm 1.11$ & 7 & $5.22 \pm 1.33$ & 7 & $5.35 \pm 5.82$ & 7 \\
Ocelot & $2.48 \pm 0.2$ & 4 & $1.8 \pm 0.24$ & 3 & $2.19 \pm 0.19$ & 3 \\
\hline
\end{tabular}

Table 5. Mean home range size $\left(\mathrm{km}^{2} \pm \mathrm{SE}\right)$ of jaguars, pumas and ocelots in different ecoregions (Olson et al. 2001).

\begin{tabular}{|c|c|c|c|}
\hline \multirow[b]{2}{*}{ ECOREGION } & \multicolumn{3}{|c|}{ SPECIES } \\
\hline & Jaguar & Puma & Ocelot \\
\hline Flooded grasslands and savannas & $116.7 \pm 27.2$ & 374.5 & - \\
\hline $\mathrm{n}$ & 3 & 1 & - \\
\hline Tropical and subtropical dry broadleaf forests & $70.2 \pm 9.1$ & $49.7 \pm 12.9$ & $5.4 \pm 1$ \\
\hline $\mathrm{n}$ & 2 & 2 & 3 \\
\hline $\begin{array}{l}\text { Tropical and subtropical grasslands, savannas } \\
\text { and shrublands }\end{array}$ & $401.2 \pm 288.9$ & 378.3 & - \\
\hline $\mathrm{n}$ & 2 & 1 & - \\
\hline Tropical and subtropical moist broadleaf forest & $84.4 \pm 27.3$ & - & $19.7 \pm 4.9$ \\
\hline $\mathrm{n}$ & 6 & - & 5 \\
\hline Desertic and xeric shrublands & - & $329.4 \pm 34$ & $5.5 \pm 2.1$ \\
\hline $\mathrm{n}$ & - & 11 & 3 \\
\hline Mediterranean forests, woodlands and scrub & - & $311.1 \pm 64.29$ & - \\
\hline $\mathrm{n}$ & - & 6 & - \\
\hline Temperate broadleaf and mixed forest & - & 69.5 & - \\
\hline $\mathrm{n}$ & - & 1 & - \\
\hline Temperate conifer forest & - & $304.7 \pm 59$ & - \\
\hline $\mathrm{n}$ & - & 10 & - \\
\hline
\end{tabular}


Table 6. Percentage of home range overlap between individuals of the same sex and between individuals of different sexes in jaguars and pumas.

\begin{tabular}{|c|cc|cc|cc|}
\cline { 2 - 6 } \multicolumn{1}{c|}{} & Intersexual overlap & \multicolumn{3}{|c|}{ Intrasexual Overlap } \\
\cline { 2 - 6 } & $\begin{array}{c}\text { Percentage of } \\
\text { overlap }\end{array}$ & $\mathrm{n}$ & $\begin{array}{c}\text { Male-Male } \\
\text { Percentage of } \\
\text { overlap }\end{array}$ & $\mathrm{n}$ & $\begin{array}{c}\text { Female-Female } \\
\text { Percentage of } \\
\text { overlap }\end{array}$ & $\mathrm{n}$ \\
\hline Jaguars & $59 \%$ & 2 & $35 \%$ & 3 & $35 \%$ & 6 \\
Pumas & $53 \%$ & 5 & $24 \%$ & 8 & $51 \%$ & 9 \\
\hline
\end{tabular}

\section{SUPPORTING INFORMATION}

Additional supporting information may be found in the online version of this article at the publisher's web-site.

Appendix S1. Bibliography and information on the studies used in the analysis of the home range of jaguars, pumas and ocelots.

Appendix S2. Bibliography and information on the studies used for the analysis of the home range overlap of jaguars and pumas. 
Appendix S3. Bibliography and information on the studies used for the analysis of the daily net displacement of pumas and ocelots.

Appendix S4: Bibliography and information on the studies used for the analysis of the distance travelled during dispersal of pumas. 


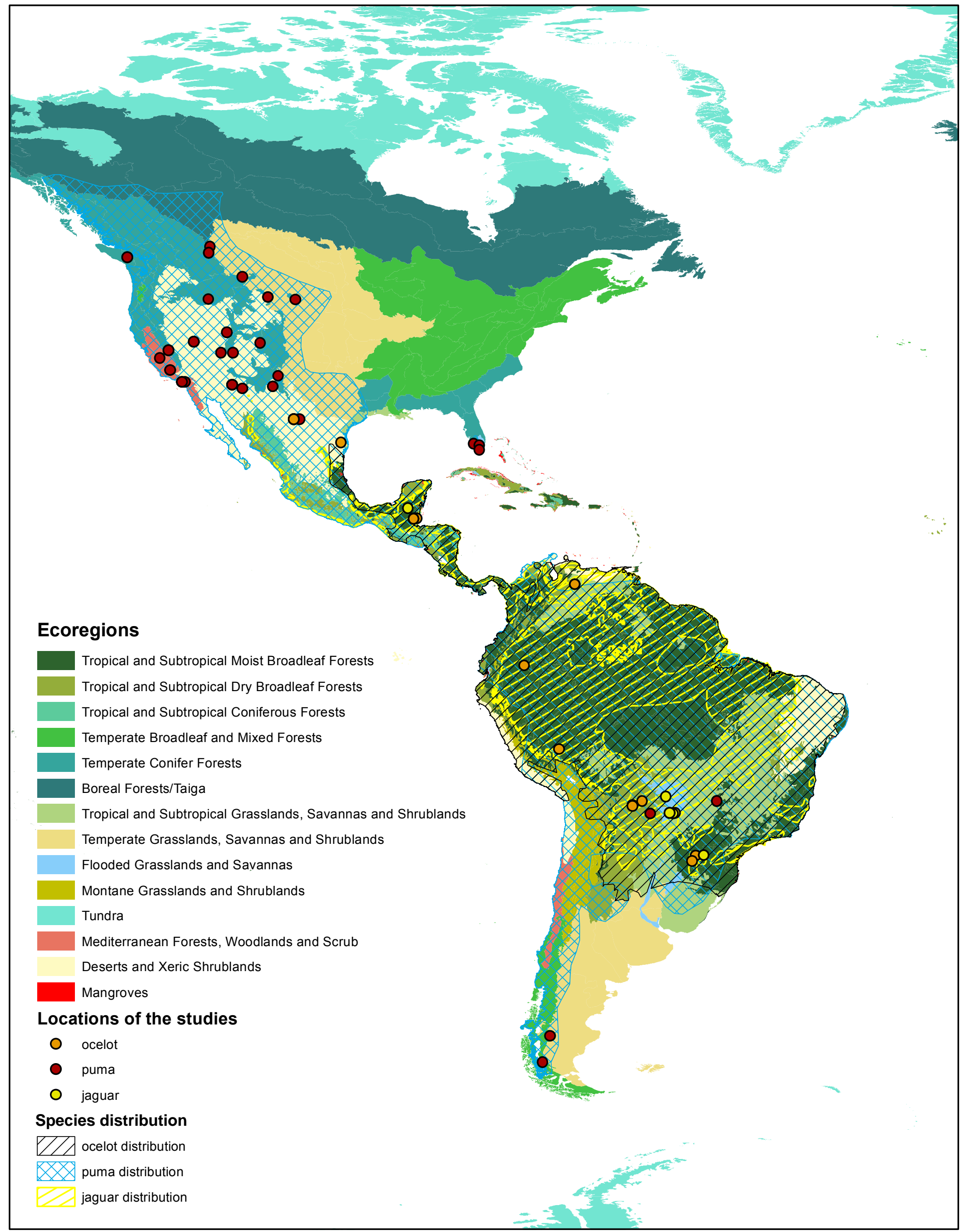




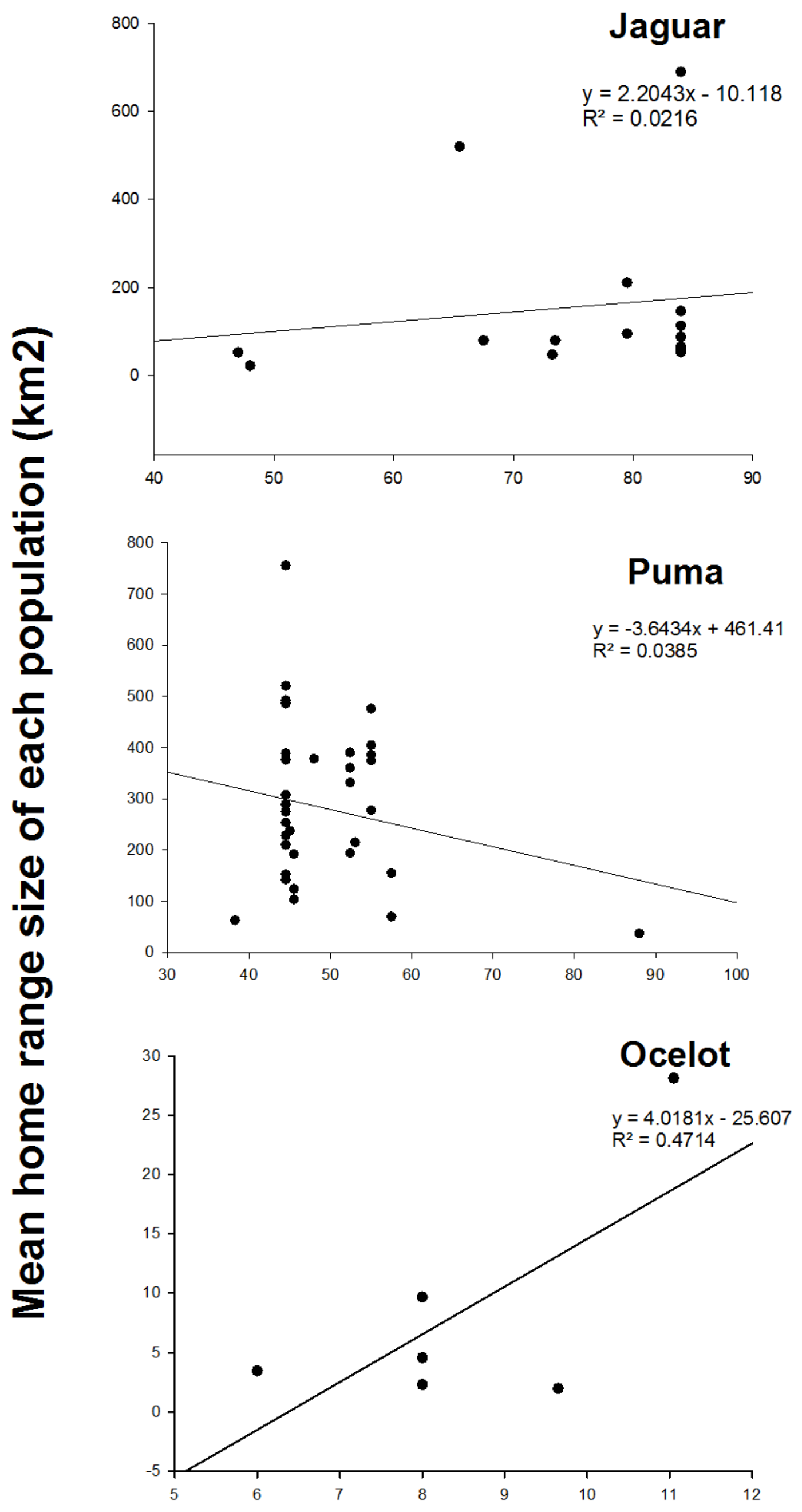

Mean body weight of each population (kg) 
a)

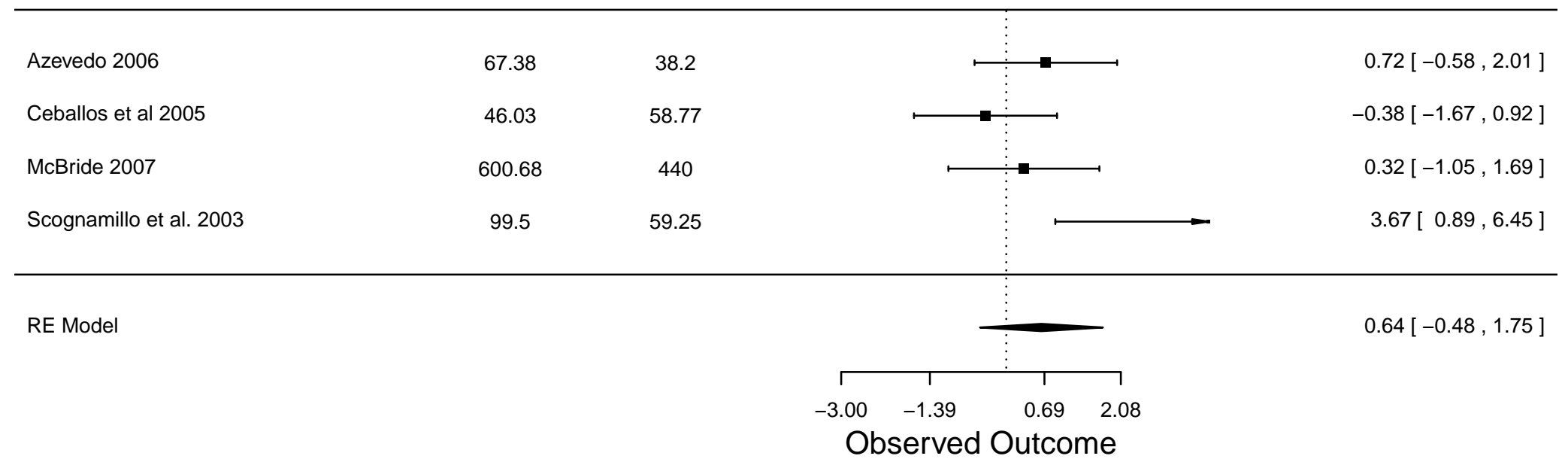

b)

\begin{tabular}{|c|c|c|c|c|}
\hline Hahn 2001 & 186 & 61 & $\longmapsto$ & $4.80[2.48,7.12]$ \\
\hline Orlando 2008 & 402.6 & 176.04 & $\stackrel{\square}{\longrightarrow}$ & $1.15[-0.21,2.52]$ \\
\hline Neal et al. 1987 & 350 & 265 & $\longmapsto$ & $0.51[-0.44,1.46]$ \\
\hline Nicholson et al. 2011 & 398.48 & 108.21 & & $1.23[0.06,2.39]$ \\
\hline Silveira 2004 & 510.33 & 246.33 & $\longmapsto$ & $0.95[-0.44,2.34]$ \\
\hline Pittman et al. 1995 & 490.5 & 318.8 & 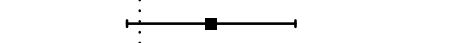 & $1.05[-0.19,2.28]$ \\
\hline Spreadbury et al. 1996 & 151 & 55 & & $2.93[0.78,5.07]$ \\
\hline Nicholson 2009 & 729.5 & 116.2 & $\longmapsto$ & $3.36[2.18,4.53$ ] \\
\hline Shackleton 2000 & 180.5 & 203.32 & $\longrightarrow$ & $-0.25[-1.66,1.15]$ \\
\hline Anderson et al. 1992 & 289.2 & 140.4 & $\longmapsto$ & $2.04[0.45,3.64]$ \\
\hline Elbroch and Wittmer 2012 & 211 & 98 & $\longrightarrow$ & $1.07[-0.20,2.34]$ \\
\hline \multirow[t]{4}{*}{ RE Model } & & & - & $1.55[0.80,2.30]$ \\
\hline & & Г & 1 & \\
\hline & & -3.00 & $\begin{array}{lll}-1.39 & 0.69 & 2.08\end{array}$ & \\
\hline & & & erved Outcome & \\
\hline
\end{tabular}

c)

Dillon and Kelly 2008

Crawshaw 1995

Tewes 1986

Dillon 2005

Maffei and Noss 2008
19.73

38.8

12.34

29

3.94
13.37

17.4

7

29.6

2.99
$1.61[0.42,6.11]$

$3.97[1.16,13.57$ ]

3.03 [ $0.78,11.77$ ]

0.96 [0.26, 3.52 ]

$2.08[0.50,8.58]$

RE Model

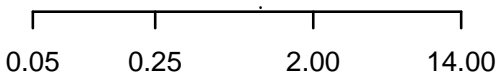

Observed Outcome 
a)

Jaguars

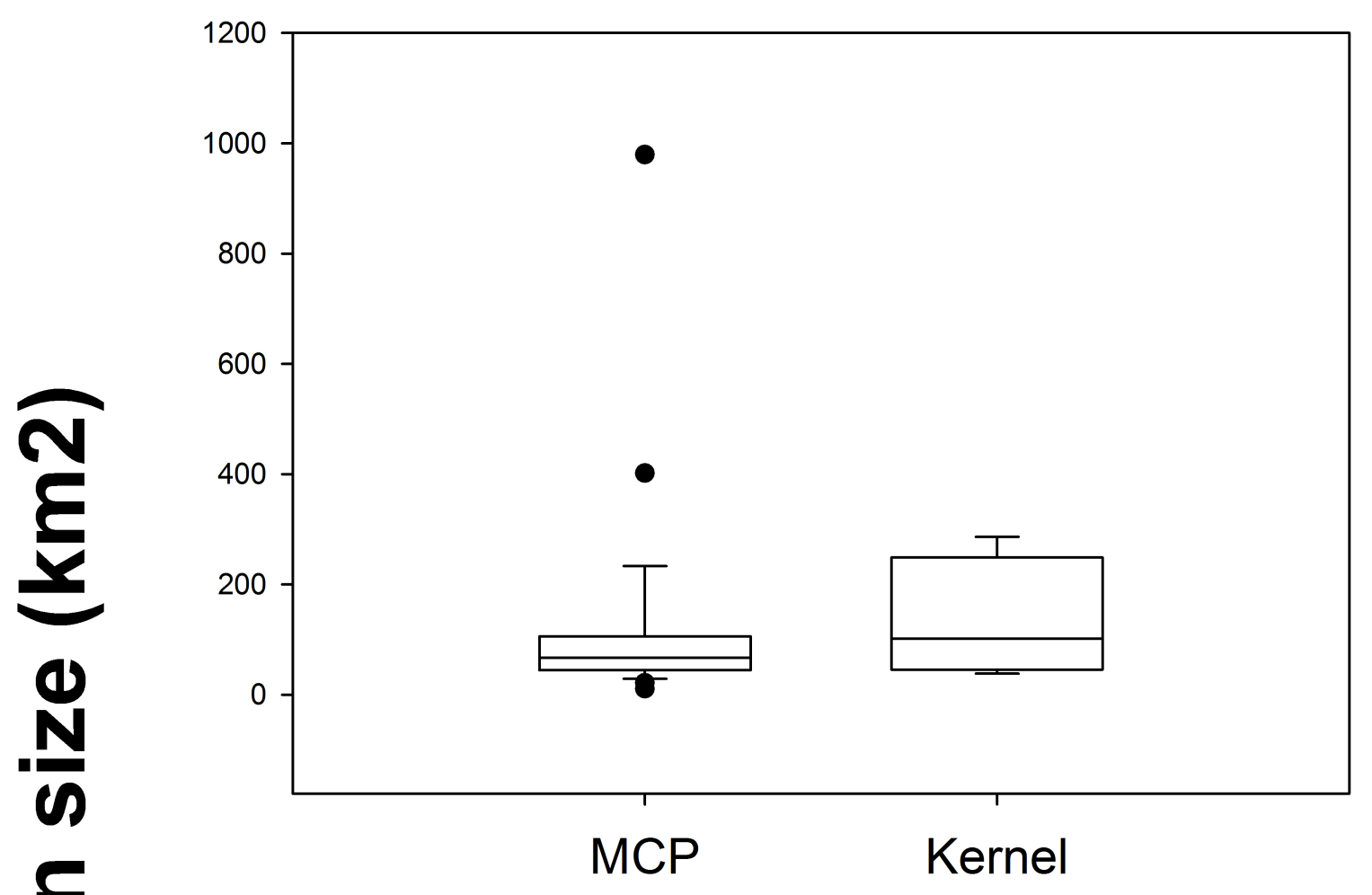

(્)

b) Pumas

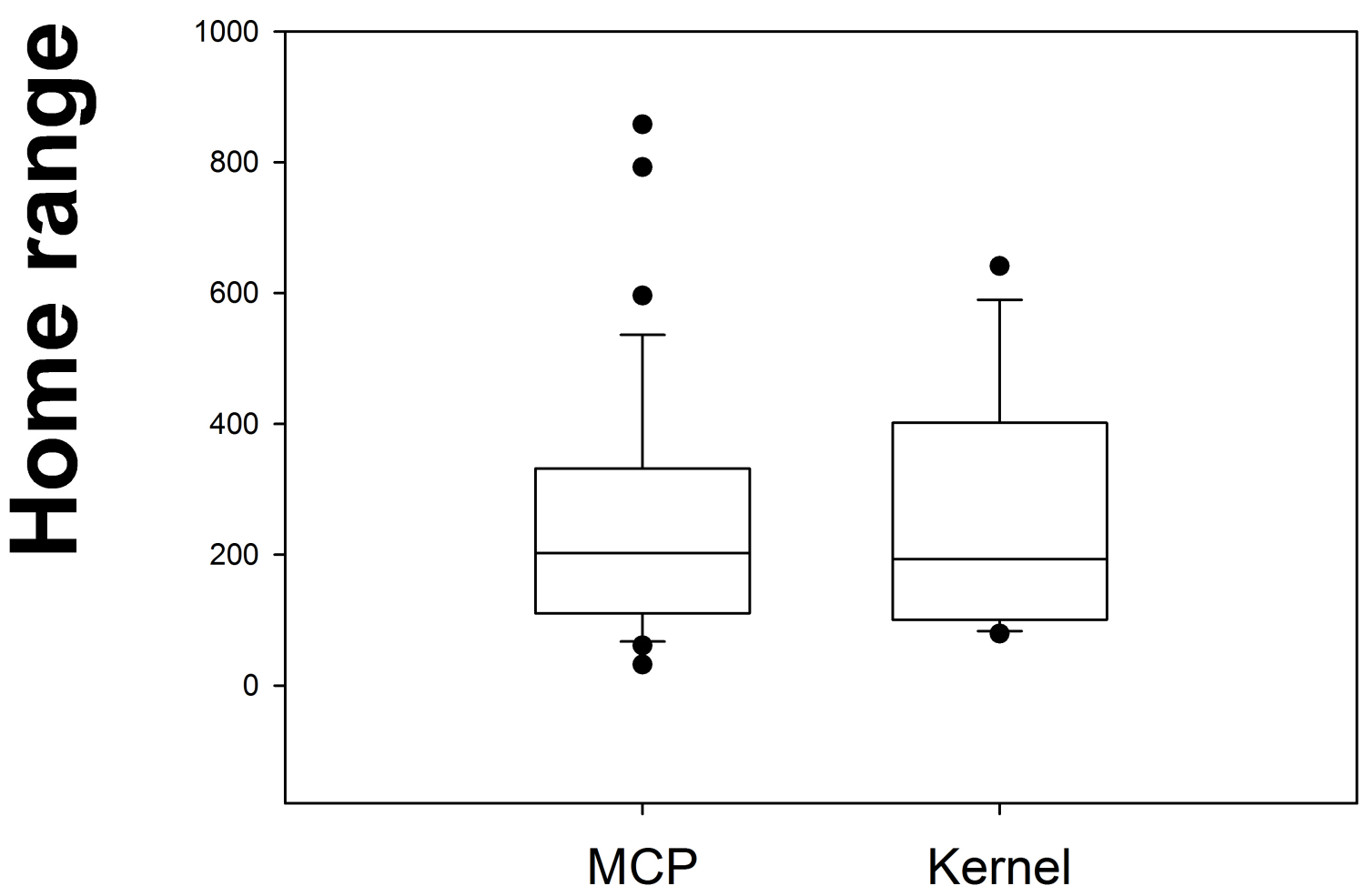

Home range estimating method 